\title{
Innovation and development of self-sustained wooden residues blocks "Madeblock" for homes and buildings
}

\section{Innovación y desarrollo de block de residuos de madera autosustentable "Madeblock" para viviendas y edificios}

\author{
DELGADO-MARTÍNEZ, Martha Lilia†*, AGUIRRE-OROZCO, Mario Abelardo, MÁRQUEZ- \\ MONÁRREZ, Olivia and OCHOA-TERRAZAS, Raúl Eduardo
} Tecnológico Nacional de México, Campus Delicias, Technological Walk km. 3.5, C.P. 33000. Cd. Delicias, Chihuahua,
Mexico.

\author{
ID $1^{\text {st }}$ Author: Martha Lilia, Delgado-Martínez / ORC ID: 0000-0002-5635-6853 \\ ID $1^{\text {st }}$ Co-author: Mario Abelardo, Aguirre-Orozco / ORC ID: 0000-0002-6899-5230 \\ ID $2^{\text {nd }}$ Co-author: Olivia, Márquez-Monárrez / ORC ID: 0000-0001-8549-5935 \\ ID $3^{\text {rd }}$ Co-author: Raúl Eduardo, Ochoa-Terrazas / ORC ID: 0000-0003-3867-8661
}

DOI: $10.35429 / J A D .2020 .11 .4 .29 .35$

Received January 25, 2020; Accepted June 30, 2020

\begin{abstract}
The south-central region of Chihuahua State has 150 transformation industries of timber forest resources, these industries dedicate to produce different types of timber furniture, which generates a huge amount of organic scraps that are deposited mostly in the intermunicipal landfill that covers 5 municipalities. Within the field research, it was detected that only one of all companies produces 20 tons of scrap per week. Hence, it is considered ground-breaking developing a model to produce sawdust blocks destined to build sustainable houses and buildings. In order to frame this research, it was also analyzed the problem of September $19^{\text {th }}, 2017$ earthquakes, presented in the following states of the Mexican Republic, Oaxaca, Chiapas, Puebla, Morelos and Mexico City, where 111,668 houses and buildings had a partial damage and 60,302 had a total damage, in other words, there were 171,990 affected houses and buildings. The prototype's construction was developed by performing destructives and mechanical resistance tests, inside the testing laboratory of a social enterprise, La Cosa in Delicias City, a town of Chihuahua State, which is accredited by the EMA (Entidad Mexicana de Acreditación).
\end{abstract}

Innovation, Sawdust Block, Sustainable Environment

\begin{abstract}
Resumen
La región centro sur de Chihuahua, cuenta con 150 industrias de transformación de recursos forestales maderables, que se dedican a fabricar diferentes muebles de madera, generando gran cantidad de residuos orgánicos, que son depositados en su gran mayoría en el relleno sanitario intermunicipal, que comprenden cinco municipios. Dentro de la investigación de campo, se detectó que únicamente una de estas empresas produce 20 toneladas de scrap por semana, es por esta razón que se considera muy novedoso desarrollar un modelo para fabricar blocks de aserrín, que con ellos se puede construir viviendas y edificios con este tipo de materiales. También para realizar esta investigación, se analizó la problemática presentada en los sismos del 19 de septiembre del 2017, en los siguientes estados de la República Mexicana, Oaxaca, Chiapas, Puebla, Morelos y Cd. de México, donde se identificaron 111, 668 viviendas y edificios que tuvieron un daño parcial y 60,302 con daño total lo que da un total de 171 mil 990 viviendas y edificios afectados. La construcción del prototipo se desarrolló realizando pruebas destructivas y de resistencia mecánica en el laboratorio de pruebas con razón social, La Cosa en Cd. Delicias Chihuahua, mismo que se encuentra acreditado ante la EMA.
\end{abstract}

Innovación, Block de Aserrín, Medio Ambiente Sustentable

Citation: DELGADO-MARTÍNEZ, Martha Lilia, AGUIRRE-OROZCO, Mario Abelardo, MÁRQUEZ-MONÁRREZ, Olivia and OCHOA-TERRAZAS, Raúl Eduardo. Innovation and development of self-sustained wooden residues blocks "Madeblock" for homes and buildings. Journal Architecture and Design. 2020. 4-11:29-35.

\footnotetext{
* Correspondence to Author (Email: mldelgamar@hotmail.com)

$\dagger$ Researcher contributing as first author.
} 


\section{Introduction}

Delicias City, a town of Chihuahua State, is known as an important region that develops the timber industry, Mexico's pioneer in timber forest resources transformation. Despite there are 150 factories involved in timber furniture fabrication, only one company of all produces 20 tons of sawdust. This research describes the reuse of this material, with the purpose of building prototypes elaborated with the thrown away scrap, and consequently, generate a decrease in environmental contamination. Therefore, the need of creating this input for the construction industry appears, optimizing the process and so on avoiding the concentration of the scrap sent to the intermunicipal landfill of Chihuahua State south-central region. To collocate the prototype in constructions, epoxy resin will be used as adhesive, to attach the block in the house and buildings walls. This objective is supported by the relevance of testing its properties and mechanical resistance, allowing to develop more sustainable and comfortable constructions. The purpose is to construct a sawdust block able to be used as a material in the construction of more sustainable houses, with a stable temperature and comfortable to its owners, because the wood's properties allows to keep isolated a place, according to the given use, thereby it may result in the construction of a more economical construction way to a conventional house.

\section{Justificaction}

This project exposes the reasons why it is important to develop this type of research, since there is already developed an environmentally sustainable block, which has the mechanical resistance properties tested on a laboratory certified by the EMA (Entidad Mexicana de Acreditación). Its resistance supports up to 58 $\mathrm{kg} / \mathrm{cm}^{2}$, accrediting harness tests and behaving as a lightweight block prototype in contrast to its special weight for seismic zones. It was also analyzed the problem of September $19^{\text {th }}, 2017$ earthquakes, presented in the following Mexico states, Oaxaca, Chiapas, Puebla, Morelos and Mexico City, where 111,668 houses and buildings had a partial damage and 60,302 had a total damage, in other words, there were 171,990 affected houses and buildings.
The prototype's construction was developed by performing destructives and mechanical resistance tests, inside the testing laboratory of a social enterprise, La Cosa in Delicias City, a town of Chihuahua State, which is accredited by the EMA (Entidad Mexicana de Acreditación).

The importance of this project is to focus on how to reduce this type of contamination, due to it is a serious problem, eminently presented in the last years and currently affecting in a direct way the environment. As mentioned before, sawdust coming from those manufacturing process represents a huge number of tons, hence, this research stablishes reuse alternatives, so that the contaminant effect decreases. This block prototype's innovation, build from sawdust and other adhesives, has proven to be a durable and resistant material, on account of that, combined with the adhesives is formed a compound strong enough to construct buildings able to support great mechanical stress, not only under high or low climatic conditions, as strong winds, but also to any other phenomena of nonextreme magnitude. Creativity is based on the thermic and mechanical properties of the block, proved on deformation stress test performed on the laboratory.

\section{General objective}

To reuse the scrap thrown away by the companies that produce different types of timber in the south-central region of Chihuahua State, and convert it into input for the construction industry, through the analysis of destructive mechanical resistance tests, in the laboratory La Cosa located in Delicias City and accredited by the EMA (Entidad Mexicana de Acreditación). Furthermore, developing different material engineering tests, in order to exploit the scrap derived from the manufacturing process performed by the furniture companies, and to transform it into a more lightweight and environmentally sustainable block. 


\section{Problem statement}

The huge number of timber scrap coming from the furniture companies is only used by brickworks as an energizer in the brick firing process or deposited in the intermunicipal landfill, located in the south-central region of Chihuahua State. Within the field research, it was detected that only one of all companies produces 20 tons of scrap per week. Hence, it is considered ground-breaking developing a model to produce sawdust blocks, in other words, use the scrap produced from the furniture manufacturing as an input to the construction industry.

\section{Theorical framework}

According to CANACINTRA (Cámara Nacional de la Industria y la Transformación, 2018) data, Delicias City has 150 furniture industries, therefore the amount of this sector's produced scrap reaches a large percentage. As mentioned by Monroy, A. (2018), in the problem of pollution we find a large number of industries that generate non-hazardous waste that occupy large volumes without providing any benefit. For this reason, it is required to know the amount and types of scrap generated by these industries, in favor of recognizing which of those are potentially valuable; acknowledging that natural degradation of the furniture industry scrap is almost null. So that it is considered ground-breaking having a way to produce construction blocks from sawdust scrap of furniture industries located in Delicias City; according to Martínez, and García, M., \& Martínez, E. (2004), it is considered a viable business with multiple benefits as of the possible profits, the growth of the regional economy and the decrease of its impact on the environment. It was also analyzed the problem of September $19^{\text {th }}$, 2017 earthquakes, presented in the following Mexico states, Oaxaca, Chiapas, Puebla, Morelos and Mexico City, where 111,668 houses and buildings had a partial damage and 60,302 had a total damage, in other words, there were 171,990 affected houses and buildings (Secretaría de Desarrollo Territorial Urbano, 2018). The prototype's construction was developed by performing destructives and mechanical resistance tests, inside the testing laboratory of a social enterprise, La Cosa in Delicias City, a town of Chihuahua State.

\section{Innovation description}

It is developed a new paradigm in the daily production of a concrete block, replacing this component for sawdust and an adhesive binder. Sawdust is an eco-friendly material, as easy to obtain that furniture manufactures give it to any people who can pick it up. By constructing the Madeblock, sawdust will be reused, because it meets the laboratory mechanical resistance tests, has a low economical cost and specially, it has the correct properties that in case of an earthquake it would reduce the accident risks of losing a live by falling into a person, due to its lightweight in contrast to a normal concrete block.

Madeblock originates from two principal benefits, the first is to optimize the sawdust by giving an added value and the second is to take care of the environment.

\section{Competitive advantages:}

- There is no other product elaborated with the same components.

- It has a lower cost than a traditional block.

- It is more lightweight than other blocks.

- By impacting against a person, it hurts less.

- $\quad$ It is eco-friendly.

- A use is given to the timber scrap.

- Its construction is profitable.

- $\quad$ It reduces the installation time.

- It has a mechanical resistance of 58 $\mathrm{kg} / \mathrm{cm}^{2}$.

\section{Production methods}

The fabrication procedure is explained, according with W. NIEBEL, Benjamin, (1998), by an illustration of a flow process diagram, because it is a graphic representation of the operations, transporting, inspections, delays and storages sequences occurring during the process. 
The flowchart below includes information considered desirable to the analysis, for instance, the necessary time and traveled distance, are especially useful to bring out hidden cost, as traveled distance, temporal storages, delays, etc.

The following points are elemental in the flow process diagram and must have special attention:

\section{- Material handling.}

- $\quad$ Plant and equipment distribution.

- Delay times.

- $\quad$ Storage times.

Figure 1 shows the sawdust block's production process, named as Madeblock.

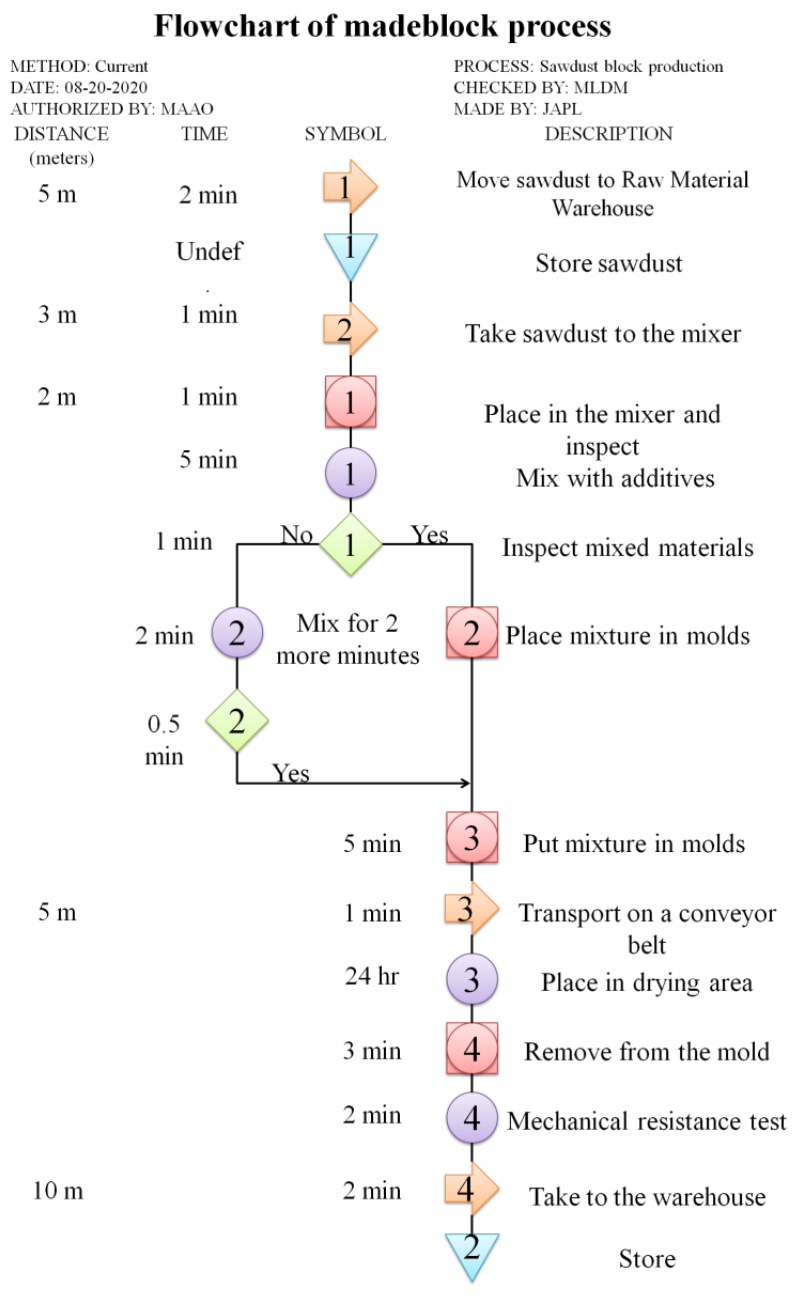

Figure 1 Madeblock Flowchart Source: Own elaboration

\begin{tabular}{|l|c|r|r|r|}
\hline \multicolumn{1}{|c|}{ Activity } & \multicolumn{1}{c|}{ Symbol } & Quantity & \multicolumn{1}{c|}{ Time } & Distance \\
\hline Operation & $\bigcirc$ & 4 & $9 \mathrm{~min}$ & \\
\hline Inspection & $\diamond$ & 3 & 1.5 & \\
\hline Transport & $\varnothing$ & 4 & $6 \mathrm{~min}$ & $28 \mathrm{~m}$ \\
\hline $\begin{array}{l}\text { Combined } \\
\text { Op. }\end{array}$ & $\bigcirc$ & 4 & $11 \mathrm{~min}$ & \\
\hline Storage & $\nabla$ & 2 & Undef. & \\
\hline
\end{tabular}

Table 1 Summary table

Source: Own elaboration

In brief, Table 1 presented above, shows that in order to produce a set of blocks, four operations were required, using a time of 9 minutes; two inspections in a total time of 1.5 minutes, four transports in 6 minutes and travelling a 27 meters distance, four combined activities in 11 minutes and two storages, one at the beginning and the other one at the end, where the storage time is undefined; totalizing a time of 27.5 minutes of process and a travelled distance of 28 meters. Since storages are undefined, it will depend on marketing and sells the production of Madeblock.

\section{Interview with experts}

The furniture producer's union of Delicias City, dependent of CANACINTRA, was visited and it was affirmed that there is a huge amount of scrap tons thrown away and by not being used, it is a contamination source that ends in the landfill. The union indicated that there are currently 150 companies dedicated to the production of furniture along the region, according to the existing database of CANACINTRA (2008), Delicias City produces huge amounts of sawdust after transforming the input (wood); and from an environmental point of view, the saturation of intermunicipal landfill spaces leads to an increase in the contamination. Madeblock can be used in seismic zones so in case of an earthquake, its lightweight property in contrast to traditional concrete blocks can reduce the risk of an accident or losing a life. In this manner, the objective is to use the huge amounts of scrap thrown away by those factories, so that the materials no longer are contaminant trash and are converted into a new product, Madeblock. 
Figure 2 shows an example of the block prototype build with sawdust thrown away by furniture producers of the south-central region in Chihuahua State.

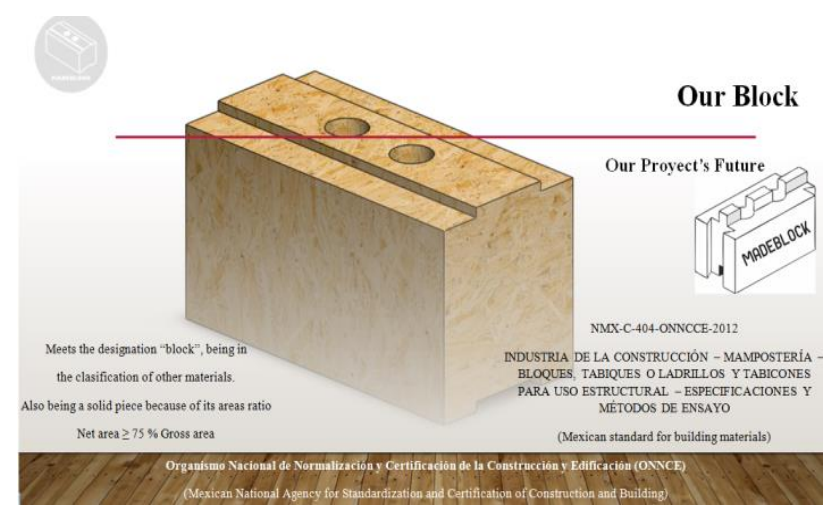

Figure 2 Protytipe developed out of wood residues Source: Own elaboration

\section{Potencial market}

In terms of this research, it is considered as potential market everyone that consumes any type of block, including high resistance block, land block, cement block, thermic block, decorative brick and marbles, among others. The project of sawdust block production and merchandising has a potential market in Delicias City of 39,093 potential customers, according to the INEGI (Instituto Nacional de Estadística y Geografía, 2015). These potential customers are mostly men dedicated to construction; nevertheless, the number of potential customers increases as far as the diffusion of the project is taken, even reaching a national and international market.

\section{Target market}

The target market are small, medium and large companies dedicated to the construction industry and the population of the south-central region of Chihuahua State and eventually it will be projected with the view of reaching international and national markets, leaded to any customer willing to change its actual construction product for the proposed product, Madeblock; leaving other used materials as concrete blocks, bricks and other building ways.

\section{Competing technologies}

Currently, there is no product fabricated with the same components of Madeblock; thereby, the only competence are lightweight blocks used for unloaded walls and dividing walls, as well as those which have self-assembly system and those produced from industrial scrap of traditional materials mix. Figure 3 shows the possible competitors as national stablished brands, highlighting Block Térmico FARLIC ®, Block ARMO ${ }^{\circledR}$, MagPanel IBUILTEC $\AA$ and Bloqueplás ${ }^{\circledR}$ de Ecoplasso.

\section{Competitive advantages of Madeblock:}

- Madeblock does not require materials for its adhesion, meanwhile FARLIC requires traditional materials.

- Madeblock can interconnect with other similar block, meanwhile Magpanel requires specific connectors.

Madeblock ensures restraint to lateral displacement, meanwhile Bloqueplás requires construction rods.

- Madeblock inputs recollection is easier and more economic than the one from PET of Bloquepás.

- Madeblock is produced from industrial resources, meanwhile the competence exploits natural resources to elaborate the blocks.

- Madeblock production implicates an easier process involving a less amount of energetic resources and polluting emissions into the atmosphere.

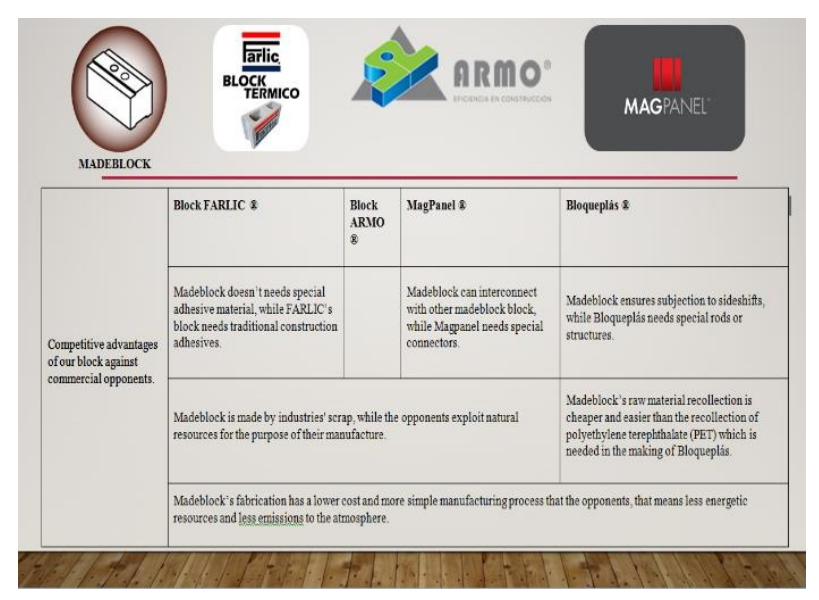

Figure 3 Madeblock CANVAN

Source: Own elaboration 


\section{Barriers to entry into the market}

Some of the barriers for the product entering and successfully positioning in the market are the high differentiation of the existing products, since in the construction industry there is a considerable block supply, as well as bricks and marbles, among others. Taking into consideration that competitors are already positioned in the costumers' mind, Madeblock requires to invest in marketing, not only money but also time and effort, so it can success in entering the market. Economy of scale represents another barrier to entering the market, because the production volumes have a repercussion in efficiency, therefore when the production amount increases, the production cost decreases. This condition benefits big construction companies and it represents a challenge to compete against those companies. For this reason, it is projected to growth in short term so Madeblock can be produced at large scale and decrease its costs.

\section{Technical and financial pre-feasibility}

It is projected a production of 652,800 pieces of sawdust block per year, by involving four employees in its start (hired as general staff), this production requires $\$ 223,279.62$ Mexican Pesos, $40 \%$ equity financed corresponding to $\$$ 89,311.84 Mexican Pesos, and 60\% debt financed corresponding to $\$ 133,967.76$ Mexican Pesos. The investment distributed as follows: a current investment of $\$ 85,279.98$ Mexican Pesos that represents the opening of the company for the first three months, a fixed investment of $\$ 99,999.62$ Mexican Pesos that includes salaries of the employees (four general staffs and a manager), the local's rent, and basic services, including electricity, drinking water, vigilance, accounting fees, freights for $\$ 78,500$ Mexican Pesos; and a differed investment of $\$$ 38,000 Mexican Pesos that covers the constitutive act and the prepaid rent for one year.

\section{Financial feasibility}

The financial viability analysis and assessment, sustained by Baca Urbina, (2001) in project formulation and evaluation, concludes that the business plan is profitable. According to the Net Present Value (NPV) of \$545,338.38 Mexican Pesos it is possible to start the business and generate an Internal Rate of Return (IRR) of $78.29 \%$, in contrast with the Weighted Average Cost of Capital (WACC) of $19.18 \%$; this satisfies the rule of IRR > WACC. On the whole, it is possible to cover the assessment rate cost and besides generate profit. This project has an approximate number of potential customers of 39,093 in the southcentral region of Chihuahua State. Since the nature of a Corporate Social Responsibility (CSR) has interference in the national and international market, Madeblock is projected to reach those markets in short term. The financial feasibility assessment was performed by giving this block a price of \$ 1.18 Mexican Pesos.

\section{Intelectual property}

Madelock will adopt the patent registry before the IMPI (Instituto Mexicano de la Propiedad Industrial) (2019) belonging to the Secretaría de Economía, because it is considered as a product. According to the search criteria until today there is no record of a similar patent of Madeblock. The simple search was performed in

https://siga.impi.gob.mx/newSIGA/content/com mon/busquedaSimple.jsf by looking for patents, brands and contentious proceedings, including the exact phrase, all words and some of the words, on all information of the published registers. The specialized search was performed in

https://siga.impi.gob.mx/newSIGA/content/com mon/busquedaEspecializada.jsf, which allows to search by exemplar type and date range. The exemplar search was performed in https://siga.impi.gob.mx/newSIGA/content/com mon/descargaEjemplares.jsf, which allows to search by exemplar type, publication type and exemplar year, and it is possible to download the exemplar in PDF and XML format (only electronic exemplars). 
Additionally, a Corporate Identity Patent will be process to protect the brand and the product's technical innovation, categories found in industrial property. The patent before the Instituto Mexicano de la Propiedad Industrial (IMPI) will allow to exploit the invention for 20 years.

\section{Results}

This research project develops a solution to the problem of huge amount of scrap produced by the furniture manufactures in Delicias City, which contributes to increase environmental contamination. Moreover, it obtains new materials to innovative sustainable buildings, that can be used in houses and households, by also bringing a better resistance to large earthquakes. The research is focused on a universe of 300 regional companies of which comprehends constructors and hardware stores.

\section{References}

Baca Urbina, (2001). Formulación y Evaluación de proyectos. País México. Editorial Mc Graw Hill.

CANACINTRA, Delicias, (2018). Cámara Nacional de la Industria de la Trasformación. Cantidad de fábricas establecidas y dedicadas a la construcción de muebles en Delicias, Chihuahua

EMA (2018). Entidad Mexicana de Acreditación. Gobierno Federal https://www.gob.mx/se/articulos/la-propiedadindustrial-en-mexico

INEGI (2015). Instituto Nacional de Estadística y Geografía. Preconteo de Encuesta Intercensal. País México.

Martínez, y García, M., \& Martínez, E. (2004). Impacto ambiental de residuos industriales de aserrín y plástico. Avances, 99.

Monroy, A. (2018). Integración de aserrín en la fabricación de bloques de concreto. Monterrey, N.L: ITESM.

Secretaría de Economía. (IMPI, 31 de mayo de 2019). Blog. Obtenido de La Propiedad Industrial en México:
SEDATU (2018) Secretaria de Desarrollo Agrario y Territorial Urbano. Gobierno Federal. País México.

W. NIEBEL, Benjamín, (1998). INGENIERIA INDUSTRIAL, Métodos, Tiempos y Movimientos, novena Edición, México, Alfaomega. 